University for Business and Technology in Kosovo

UBT Knowledge Center

Oct 28th, 5:00 PM - 6:30 PM

\title{
Investigation of Kosovar, Albanian, Bosnian and Turk Adolescents' Attitudes Toward Violence
}

\author{
Elmedina Çesko \\ University for Business and Technology, elmedina.cesko@ubt-uni.net
}

Follow this and additional works at: https://knowledgecenter.ubt-uni.net/conference

Part of the Psychology Commons

\section{Recommended Citation}

Çesko, Elmedina, "Investigation of Kosovar, Albanian, Bosnian and Turk Adolescents' Attitudes Toward Violence" (2017). UBT International Conference. 327.

https://knowledgecenter.ubt-uni.net/conference/2017/all-events/327

This Event is brought to you for free and open access by the Publication and Journals at UBT Knowledge Center. It has been accepted for inclusion in UBT International Conference by an authorized administrator of UBT Knowledge Center. For more information, please contact knowledge.center@ubt-uni.net. 


\title{
Investigation of Kosovar Albanian, Bosnian and Turk Adolescents' Attitudes Toward Violence
}

\author{
Elmedina Çesko
}

UBT - Higher Education Institution

\begin{abstract}
This research investigates the attitudes towards violence of three ethnic groups in Kosovo and adolescents' cultural aspects. The aim of the research is to investigate whether the attitude of violence of Kosovo Albanian, Bosnian and Turk adolescents show a significant difference according to ethnic group and gender.

The sample of the research was recorded separately from each ethnic group. From the Albanian ethnic group, a total of 300 adolescents, from the Bosnian ethnic group a total of 200 adolescents, and from the Turkish ethnic group a total of 200 adolescents, in total 700 adolescents participated in the research. For data collection the "Attitudes towards Violence" scale was adapted in the three languages. The number of adolescents that took place during this application in total is 359 . The findings of the research showed a significant difference between the attitudes towards violence and ethnic groups, where the Albanian ethnic group manifested more violent attitudes than the other two ethnic groups. In addition, it was found that Bosnian adolescents confirm more violent attitudes than Turkish adolescents. In many of the researches that have been done among ethnic groups, minority groups seem to be more aggressive than majority groups. However, this study showed that, despite being a majority group, Albanians approved a higher level of violence and the situation was discussed by the literature supporter. The findings are similar to the survey results, and significantly higher level of difference were found in attitudes towards violence by gender in male adolescents than female adolescents in all ethnic groups. These findings suggest that gender is an important risk factor of violence. Lastly, the interaction of common influence of the ethnic group and gender in attitudes toward violence has not been found significant.
\end{abstract}

Keywords: Attitudes towards violence, Kosovo's Albanian Bosnian Turks, ethnic group, adolescents, gender.

\section{Introduction}

Although violence is as old as human history, it was not perceived as a serious problem till this century. Violence increases day by day as an experienced phenomenon (Kapıcioğlu, 2008). Violence is posed inmany ways, such in abused and neglectedchild,force using, in sexual abuse andin elder abuse.

The World Health Organization (2002) defines violence as: “ The intentional use of physical force or power, threatened or actual, against oneself, another person, or against a group or community, that either results in or has a high likelihood of resulting in injury, death, psychological harm, maldevelopment or deprivation.".Indeed, in the developed and developing countries of the 21 st century, violence continues to exist as one of the social problems. The presentation of various forms of violence in visual and written media, the way violence is exercised and the exposure of certain violent behaviors in proportions that encourage them to 
cause violence to maintain its existence in everyday life and to gain a permanent place (Çetin, 2004).

According to world statistics, adolescents are particularly disadvantaged groups to be adversely affected by the consequences of violence. Violence caused by adolescents is one of the most prevalent forms of violence in society. In this period, when adolescents are looking for a new identity, moving away from the family and the people they consider to be an authority they tries to stand on their feet.Adolescence and young adulthood are defined as periods of increased violent behavior(Dahlberg and Potter, 2001).

The attitudes of adolescents towards problem behaviors determine the tendency to addressing to violence (Sussman, Skara, Weiner and Dent, 2004). In the tendency of using violence is included adolescent's personal or psychological characteristics and anti-social attitudes toward aggression or violence.It is possible that these persons show aggressiveness, bullying and anti-social behavior (Cunningham, Henggeler, Limber, Melton and Nation, 2000).

In most of the time attitudes have an important influence on behavior, especially on violent behavior (Funk et al., 1999). Surveys show that positive attitudes towards violence are an important risk factor of aggressive behavior (Markowitz, 2001). Funk et al. (1999) suggests that the youth who were the victims of violence have stronger attitudes toward violence.

Current situation and living conditions in Kosovo also is affecting education and academic areas. Lack of financial support that universities have, research and application deficiencientconditions, lack of bibliography and libraries make it difficult for universities to do research and at the sameis limiting the number of researches (Center for Political Courage, 2013).

According to Chandra (2006), while many studies have focused on ethnic identity and ethnic differences, the effects of ethnic rivalry in ethnic violence have not been taken into consideration. There are only a limited number of researches in this area (Chandra, 2006).

Ethnic identities are defined by typical rules of group members in cultural content qualitiesand the characteristics of cultural content where isinvolved religion, language, norms and habits(Fearon and Laitin, 2000).Adolescence is the basic stage in which a person create a lifelong identity.Many aspects of identity is developing during this stage, where is also includedethnic or ethnic group identity (Greig, 2003).In multicultural societies, in development of person an important factors are cultural and group identity as well as is individual characteristics (Jain, 2005).

In previous researches on attitudes toward violence generally was examined gender and age variables. Most of the researches that measure attitudes towards violence and study ethnicity were done in United States of Amerika.On the other side, in Kosovo even in the last years researches are increasing but in general there are limited number of researches. Is not found any studies that has been done between ethnic groups which investigate attitudes towards violence based in ethnic group factor.Another great advantage of the research is that it will be implemented in Kosovo so,since no research has been done before,that directly measures adolescents' attitudes towards violencethis research has importance thatis going to be the first in this area.It is supposed that this research will make a significant contribution to Kosovo's and world-wide's literature in this study area. 


\section{Methodolgy}

This research is a relational research of high school students were is showing attitudes towards violence among Albanian, Bosnian and Turkish teenagers It was investigated whether the attitudes of adolescents studying in Albanian, Bosnian and Turkish languages were significantly different according to ethnic background and gender variables. Attitudes Towards Violence Attitude Sale was first adapted on high school students in three languages, Albanian, Bosnian and Turkish and after completing the study of language adaptation the scale is applied to 700 high school adolescents.

\section{Sample}

Participant adolescent's ethnic group, age and gender distribution of the survey are below in Table 1.

Table 1. Sample distribution

\begin{tabular}{lllllll}
\hline Ethnic group & \multicolumn{6}{c}{ Gender } \\
\hline & \multicolumn{3}{c}{ Female } & \multicolumn{2}{c}{ Male } & \multicolumn{2}{c}{ Total } \\
\cline { 2 - 7 } & $\mathrm{n}$ & $\%$ & $\mathrm{n}$ & $\%$ & $\mathrm{n}$ & $\%$ \\
\cline { 2 - 7 } Albanian & 166 & 55.3 & 134 & 44.7 & 300 & 42.9 \\
Bosnian & 82 & 41.0 & 118 & 59.0 & 200 & 28.6 \\
Turks & 118 & 59.0 & 82 & 41.0 & 200 & 28.6 \\
Total & 366 & 52.3 & 334 & 47.7 & 700 & 100.0 \\
\hline
\end{tabular}

\section{Data collection and language adaptation's forms}

In order to be able to investigate the attitudes of adolescents towards violence is used "Attitudes Towards Violence Scale"developed by Anderson, Benjamin, Wood, and Bonacci (2006). The scale consists 39 items and is scored in a five point Likert scale: $1=$ Strongly Disagree, $2=$ Disagree, $3=$ Neither Agree or Disagree, $4=$ Agree $5=$ Strongly Agree. Having high score in total represents positive attitudes toward violence, and having low score in total represents negative attitudes toward violence. The scale aims to measure in one dimension attitudes towards violence.

The research includes three ethnic group adolescences' where each ethnic group had the scale available on their own language, which means the scale form weretranslated and adapted.in three languages, Albanian, Bosnian and Turkish.During the translation process of 39 scale items was decided to remove the $30^{\text {th }}$ item because it lost its meaning during translation. As a result of the process of language adaptation, "Attitudes Towards Violence Scale" was composed from 38 items and the adaptation study benefited from it.

Statistical Analyzes of Albanian, Bosnian and Turkish Adolescents' in language Adaptation Scale of the the survey are below in Table 2 . 
Table 2. Language adaptation analysis

\begin{tabular}{lccccccc}
\hline & N & Range & Min. & Max. & $\widetilde{\boldsymbol{x}}$ & $\mathbf{S}$ & $\boldsymbol{\alpha}$ \\
\hline Albanian & 159 & 50 & 33 & 83 & 53.44 & 10.34 & .81 \\
Bosnian & 100 & 61 & 29 & 90 & 53.73 & 12.65 & .84 \\
Turks & 100 & 89 & 26 & 110 & 52.90 & 13.15 & .85 \\
\hline
\end{tabular}

\section{Data Analysis and Results}

The research data were coded according to ethnic group and gender and it was recorded by SPSS program. In the analysis process firstly was did descriptive statistics and that it was followed by statistical analysis.In the data analysis, in order to simultaneously test the basic effect of two inter-group factors on a dependent variable and the common effect of two factors on the dependent variable (Büyüköztürk, 2002)for unrelated measures was used factorial ANOVA.

Table 3. Frequency Distribution of Adolescents' Attitudes Towards Violence

\begin{tabular}{lccccccc}
\hline Total & N & Range & Min. & Max. & $\widetilde{\boldsymbol{x}}$ & S & $\boldsymbol{\alpha}$ \\
\hline A.T.V. & 700 & 84 & 26 & 110 & 57.39 & 13.23 & .84 \\
Scale & & & & & & & \\
\hline
\end{tabular}

Table 4. Descriptive Statistics Results for Ethnic Groups and Gender of

Adolescents' Attitudes Towards Violence

\begin{tabular}{lllllllllllll}
\hline & \multicolumn{3}{c}{ Albanian } & \multicolumn{3}{c}{ Bosnian } & \multicolumn{3}{c}{ Turks } & \multicolumn{3}{c}{ Total } \\
\cline { 2 - 13 } & $\mathrm{N}$ & $\widetilde{\boldsymbol{x}}$ & $\mathrm{S}$ & $\mathrm{N}$ & $\widetilde{\boldsymbol{x}}$ & $\mathrm{S}$ & $\mathrm{N}$ & $\widetilde{\boldsymbol{x}}$ & $\mathrm{S}$ & $\mathrm{N}$ & $\widetilde{\boldsymbol{x}}$ & $\mathrm{S}$ \\
\hline Fema & 16 & 52.4 & 10.4 & 82 & 53.3 & 10.8 & 11 & 50.0 & 10.4 & 36 & 51.8 & 10.6 \\
le & 6 & 2 & 8 & & 5 & 1 & 8 & 6 & 7 & 6 & 7 & 2 \\
Male & 13 & 66.8 & 12.4 & 11 & 61.5 & 12.7 & 82 & 60.4 & 13.8 & 33 & 63.4 & 13.1 \\
& 4 & 7 & 4 & 8 & 8 & 9 & & 3 & 1 & 4 & 3 & 9 \\
Total & 30 & 58.8 & 13.4 & 20 & 58.2 & 12.6 & 20 & 54.3 & 12.9 & 70 & 57.3 & 13.2 \\
& 0 & 8 & 6 & 0 & 1 & 6 & 0 & 3 & 8 & 0 & 9 & 3 \\
\hline
\end{tabular}


Table 5. Factorial ANOVA Results for Ethnic Groups and Gender of Adolescents' Attitudes Towards Violence

\begin{tabular}{lcccc}
\hline \multicolumn{1}{c}{ Source } & $\begin{array}{c}\text { Sum of } \\
\text { Square }\end{array}$ & df & Mean Square & F \\
& 2274.53 & 2 & 1137.27 & $8.25^{*}$ \\
\hline Ethnic Group & 19981.91 & 1 & 19981.91 & $145.04 *$ \\
Gender & 1219.29 & 2 & 609.65 & 4.42 \\
Ethnic Group & & & & \\
X Gender & 95613.76 & 694 & 137.77 & \\
Error & 2427595.00 & 700 & & \\
Total & & & &
\end{tabular}

As a result of both the ethnic group and the gender analysis in attitudes toward violence was seen that the main effect of gender was significant $\left(\mathrm{F}_{1-694}=145.04, \mathrm{p}<0.001\right)$. These result are in disadvantage for male participants, where the score of attitudes toward violence were significant in 0,01 point. Also the main effect of ethnic group into attitudes toward violence was significant $\left(F_{2-694}=8.25 ; p<0,001\right)$. In other side, for defining the significance between ethnic group is used Scheffe Test analysis and the results showed that is significant for .05 level between each group.

\section{Discussion}

Hall (1996) expressed the continuity of the concept of "diversity" in racial and ethnic groups. The experienced disadvantages by people from racial and ethnic groups are caused by many negative factors.Modood et al. (1998) in their work refers that socioeconomic factors predominate within the disadvantages of different minority groups. In addition, the distresses experienced by different ethnic groups are related to the areas of sheltering, working and education(Sewell, 2009).

This research, found that the attitudes toward violence of the three ethnic groups have different norms, which dimensionof averagedifferences betweenadolescents' group can be explained. This difference between the attitude point scores of Albanian, Bosnian and Turkish adolescents is due to the different cultures they have, because the differences between attitudes towards violence is based on cultural differences (Kaza, 2006; Funk et al., 1999; Wolfgang and Ferracuti, 1982;. Kizmaz, 2006).

According to the results of the research, it is found that the attitudes towards violence are significantly different among ethnic groups, and it may have been caused by emotions such as psychological dissatisfaction, sadness, insecurity, hostility and / or alienation feeling (Balk1s et al., 2005; Gençoğlu et al., 2014; QKSGJ, 2012; Ögel et al., 2005; Özgü et al., 2011). In addition, the attitudes towards violence of the Bosnians and Turks, minority groups were lower than the Albanian group which is incompatible with the literature (Funk et al., 1999; Phinney, 1989; Sampson et al., 2005).

Looking at the historical background of Kosovo, it is seen that the country has undergone many reforms and rapid changes and transitions that it has overcome many troubles and problems. The multi-ethnic and multicultural model has strengthened day by day and all communities' legal rights are protected.These changes are thought to be concuss the feeling of belonging of Albanians as major community. Whereas, the sense of belonging is one of the most important 
factors for the healthy individual development. On the other hand, this need provides a universal, basic and psychological saturation because in other side person cannot perceive himself as an integral part of the society, and is having difficulties on creating and keeping interpersonal contacts (Murdock, 2008; BaumeisterandLeary, 1995).

\section{References}

1. Anderson, C. A., Benjamin, A. J., Wood, P. K., \&Bonacci, A. M. (2006). Revisedattitudes toward violence scale. Aggressive Behavior, 32, 122-136.

2. Balkıs, M., Duru, E., \&Buluş, M. (2005). Şiddeteyöneliktutumlarınözyeterlik, medya,şiddeteyönelikinanç, arkadaşgrubuveokulabağl1lıkduygusuileilişkili. EgeEğitimDergisi, 6 (2), 81-97.

3. Baumeister, R., \& Leary, M. R. (1995). The need to belong: Desire for interpersonalattachments as a fundamental human motivation. Psychological Bullentin, 117(3), 497-529.

4. Büyüköztürk, Ş. (2002). Faktöranalizi: Temelkavramlarveölçekgeliştirmedekullanımı. KuramveUygulamaEğitim Yönetimi 32, 470-483.

5. Center for Political Courage. (2013). HulumtimetnëshkencatshoqërorenëKosovë.Prishtinë: Regional Research, Western Balkans.

6. Cunningham, P. B., Henggeler, S.W., Limber, S. P., Melton, G. B., \& Nation, M. A.(2000). Patterns and correlates of gun ownership among nonmetropolitan andrural middle school students. Journal of Clinical Child Psychology, 29 (3), 432-442.

7. Çetin, H. (2004). Öğrenciergenlerinşiddeteyöneliktutumlarl: yaşvecinsiyetegörebirinceleme. Yayınlanmamışyükseklisanstezi. Ankara Üniversitesi, Ankara.

8. Chandra, K. (2006). What is ethnic identity and does it matter?. Annual Review ofPolitical Science, 9, 397-424. doi: 10.1146/annurev.polisci.9.062404.170715.

9. Dahlberg, L. L, \& Potter, L. B. (2001). Youth Violence:Development pathways andprevention challenges. American Journal of Preventive Medicine, 20 (1), 3-14.

10. Fearon, J. D., \&Laitin, D. D. (2000). Violence and the social construction of ethnicidentity. International Organization, 54 (4), 845-877.

11. Funk, J. B., Elliot, R., Urman, M. L., Flores, G. T., \& Mock, R. M. (1999). The attitudestowards violence scale: A measure for adolescents. Journal of InterpersonalViolence, 14 (11), 1123-1136. doi: 10.1177/088626099014011001.

12. Gençoğlu, C., Kumcağız, H., \&Ersanlı, K. (2014). Ergenlerinşiddeteğilimineetkiedenailevifaktörler. International Periodical for the Languages, Literature andHistory of Turkish or Turkic, 9 (2), 639-652.

13. Greig, R. (2003). Ethnic identity development: Implications for mental health inAfricanAmerican and Hispanic adolescents. Taylor \& Francis Health Sciences, 24, 317-331. doi: 10.1080/01612840390160810.

14. Hall, S. (2000). Who needs identity?. Inside of Gay, P., Evans, J., \& Redman, P. (Ed.).Identity: a reader (pp. 15-30). London: Sage Publications.

15. Jain, P. (2005). Balancing Minority Rights and Gender Justice: The Impact ofProtecting Multiculturalism on Women's Rights in India. Berkeley Journal ofInternational Law, 23:1 (6), 201-222.

16. Kapıcıŏlu, İ. (2008). Üniversiteöğrencilerinşiddetalgısı. Yayınlanmamışyükseklisanstezi. SelçukÜniversitesi, Konya.

17. Kaza, N. (2006). Adoleshencastina e shpërthimeve. Tiranë: Mirgeeralb. 
18. Kızmaz, Z. (2006). Şiddetinsosyo - kültürelkaynakları̈zerinesosyolojikbiryaklaşım. FiratÜniversitesiSosyalBilimlerDergisi, 16 (2), 247-267.

19. QendraKosovarepërStudimeGjinore [QKSGJ] (2012). Prania e dhunësnëmarrëdhëniet e adoleshtëve. http://www.unfpakos.org/wpcontent/uploads/2012/12/Prevalence-ofviolence-alb-finale-DRINI.pdf.

20. Markowitz, E. F. (2001). Attitudes and family violence: Linking Intergenerational andcultural theories. Journal of Family Violence, 16 (2), 205-218.

21. Murdock, N. L. (2008). Theories of Counseling and Psychotherapy. (2.nd Edition).New York: Pearson.

22. Özgür, G., Yörükoğlu, G., \&Arabac1, L. B. (2011).

Liseöğrencilerininşiddetalgıları,şiddeteğikimdüzeyleriveetkileyenfaktörler.

PsikiyatriHemşireliğiDergisi, 2(2), 53-60.

23. Phinney, J. S. (1989). Stages of ethnic identity development in minority groupadolescents. The Journal of Early Adolescence, 9 (1-2), 34-49. doi:10.1177/0272431689091004.

24. Sampson, R. J., Morenoff, J. D., \&Raudenbush, S. (2005). Social anatomy of racial andethnic disparties in violence. American Journal of Public Health, 95 (2), 224-232. doi: 10.2105/AJPH.2004.037705.

25. Sewell, H. (2009). Working with ethnicity, race and culture in mental health. London:Jessica Kingsley Publishers.

26. Sussman, S., Skara, S., Weiner, M., Dent, C. (2004). Prediction of Violence AmongHighRisk Youth. American Journal of Health and Behavior, 28 (2), 134-144.

27. World Health Organization [WHO] (2002). World report on violence and health. Access date: 31 April 2015, http://apps.who.int/iris/bitstream/10665/42495/1/9241545615_eng.pdf.

28. 